\title{
TEMA DAN NILAI KEHIDUPAN DALAM LAKON SUGAWARA DENJU TENARAI KAGAMI
}

\author{
Nina Alia Ariefa \\ Program Studi Sastra Jepang, Fakultas Sastra, \\ Universitas Al Azhar Indonesia, Jl. Sisingamangaraja, Jakarta 12110 \\ Email: nina_alia@uai.ac.id
}

\begin{abstract}
Abstrak - Penelitian ini bertujuan untuk mencari tema dan nilai-nilai kehidupan dalam lakon Sugawara Denju Tenarai Kagami. Metode deskriptif analisis digunakan untuk menganalisis kutipan dialog yang diperoleh dari korpus berbentuk teks lakon. Teori yang digunakan dalam penelitian ini adalah tiga aspek naratif yang dikemukakan oleh Tzvetan Todorov, yang meliputi pembahasan aspek sintaksis, semantik, dan pragmatik. Penelitian ini menemukan bahwa konsep kesetiaan dan pengabdian dalam konteks hubungan atasan dan bawahan menjadi tema utama dalam lakon ini. Penggambaran konsep kesetiaan dan pengabdian melalui perilaku dan ujaran para tokoh dalam lakon ini didasarkan pada kesadaran dan rasa terima kasih atas budi baik atau jasa yang pernah mereka terima dari pemberi budi. Nilai kebaikan yang tertinggi dalam konsep moral orang Jepang tergambar pada kemampuannya dalam memenuhi kewajiban-kewajiban yang mereka emban. Konsep ini pulalah yang mengatur hubungan antar individu pada masyarakat Jepang. Nilainilai kehidupan yang tergambar dalam lakon ini meliputi pemenuhan tanggung jawab, kesungguhan hati dalam menjalankan kewajiban, dan kehormatan diri.
\end{abstract}

Abstract - The research aims to explore the themes and values of life in the play Sugawara Denju Tenarai Kagami. Descriptive analysis methods was used to analyze the dialogue quotes obtained from the corpus. The theory used in this research are the three aspects of the narrative presented by Tzvetan Todorov, which includes the aspects of syntax, semantics, and pragmatics. The results show that the concept of loyalty and devotion in the context of a superior and subordinate relationship become the main theme in this play. The depiction of the concept of loyalty and devotion through the behavior and speech of the characters in the play are based on awareness and gratitude for a favor or service they have received from the donor. The highest virtue in moral concepts of the Japanese reflected in its ability to fulfill the obligations they entailed. This concept is also regulates relations between individuals in Japanese society. The fulfillment of responsibility, sincerity in performing duty, and honor are reflected as the values of life in the play.

Keywords - loyalty, obligations, moral, giri, on

\section{PENDAHULUAN}

Ningyo joruri atau yang sekarang yang lebih 1 dikenal dengan sebutan bunraku adalah salah satu dari empat drama tradisional Jepang selain noh, kyogen, dan kabuki. Ningyo joruri berasal dari kata ningyo yang berarti boneka, dan joruri yang mengacu pada teks cerita. Pada awalnya, joruri adalah cerita yang disampaikan oleh narator untuk didengarkan dan tidak disertai boneka.

Joruri diperkirakan lahir pada pertengahan zaman Muromachi, akhir abad ke-15. Joruri dibawakan dengan cara bercerita dan diiringi alat musik biwa. Akan tetapi, setelah masuknya alat musik shamisen melalui kepulauan Ryukyu pada pertengahan abad ke-16, musik pengiring joruri berganti menjadi shamisen. 
Pada akhir abad ke-16, ketiga elemen, yaitu lakon, iringan shamisen, dan boneka, digabungkan menjadi satu. Hasil penggabungan inilah yang menjadi drama ningyo joruri atau yang kemudian lebih dikenal dengan nama bunraku.

Di bawah kepemimpinan klan Tokugawa, Jepang mengalami masa kedamaian yang panjang. Saat itu, kebudayaan rakyat mengalami perkembangan yang menonjol, khususnya, di zaman Genroku (16881703). Bunraku sendiri berkembang dengan pesat pada masa ini.

Di antara lakon-lakon bunraku yang bermunculan saat itu adalah lakon yang berjudul Sugawara Denju Tenarai Kagami. Lakon ini adalah salah satu dari sandaimeisaku atau "Tiga Karya Besar" yang merupakan tiga karya terkenal dalam bunraku yang ditulis oleh gabungan penulis yang terdiri dari Takeda Izumo (1691-1756), Namiki Senryu (16951751) dan Miyoshi Shoraku (1696-1772) (Shoko, 2000:194). Lakon ini dianggap sebagai masterpiece (karya utama) teater bunraku.

Lakon ini pula banyak diadaptasi dengan kreativitas yang beragam ke dalam bentuk novel, drama, dan lain-lain, dan tetap mempertahankan kepopulerannya hingga saat ini. Inilah yang menyebabkan penulis tertarik untuk meneliti tema dan konsep/nilai-nilai kehidupan masyarakat Jepang yang terdapat di dalamnya. Dengan penelitian kesusastraan ini, diharapkan dapat memeroleh gambaran tentang kehidupan masyarakat Jepang, khususnya gambaran nilai-nilai yang berlaku pada masyarakat pada zaman Tokugawa, yang merupakan akar dari konsep/nilainilai kehidupan yang tetap ada di masyarakat Jepang hingga masa kini.

Tujuan penelitian ini adalah untuk menemukan tema dan nilai kehidupan yang terdapat dalam lakon Sugawara Denju Tenarai Kagami, dengan perumusan masalah sebagai berikut:

(1) Tema apa yang terdapat dalam lakon Sugawara Denju Tenarai Kagami?

(2) Nilai kehidupan apa yang terdapat dalam lakon tersebut?

\section{TELAAH TEORI TIGA ASPEK NARATIF}

Tzvetan Todorov, salah seorang kaum naratologi Perancis, memisahkan tiga dimensi atau aspek dari naratif. Aspek-aspek ini adalah: aspek semantik (isi), aspek sintaksis (kombinasi dari berbagai struktur unit) dan aspek verbal (manipulasi istilah ataupun frasa tertentu dalam suatu cerita).

\subsection{Aspek Sintaksis}

Teori sintaksis atau hubungan in praesentia digunakan untuk menganalisis alur cerita. Pengertian cerita dan alur cerita sering digunakan dalam arti yang berbeda-beda. Cerita adalah petanda suatu teks naratif, namun dalam telaah sastra, cerita sering disebut alur. Istilah alur sendiri digunakan untuk menunjuk serangkaian peristiwa yang saling berkaitan secara logis dan dikarenakan oleh suatu tindakan. Dalam penelitian karya sastra, langkah pertama yang dilakukan adalah menganalisis struktur cerita yang bertujuan mendapatkan susunan teks. Analisis aktan dan fungsi digunakan pada langkah ini. Analisis aktan dan fungsi merupakan analisis alur cerita yang didasari hubungan antaraktan. Menurut Greimas (1917-1992), naratologis struktural yang berasal dari Lithuania, tidak satupun cerita dapat menjadi suatu totalitas yang bermakna tanpa didasari struktur aktansial.

Dalam buku Budiman (2006: 16), dijelaskan bahwa model aktansial terdiri atas enam pola kategori; satu sama lain ditempatkan dalam relasi sintaksis serta tematik.

1. Pengirim adalah pihak yang mempunyai karsa untuk meraih objek.

2. Objek adalah sesuatu yang ingin diraih oleh keinginan si pengirim.

3. Subjek adalah seseorang (bisa juga binatang dalam mitos dan sebagainya) yang mengemban tugas dari si pengirim. Subjeklah yang melakukan pencarian objek.

4. Penolong adalah pihak yang membantu subjek dalam pencarian objek.

5. Penentang adalah pihak yang menghalangi subjek dalam pencarian objek.

6. Penerima adalah pihak yang akan menikmati dan menerima objek yang berhasil diraih subjek.

\subsection{Aspek Semantik}

Dalam pembahasan analisis semantik ditampilkan unsur yang berkaitan dengan tokoh. Todorov menyebutnya analisis in absentia. Hubungan in absentia atau hubungan paradigmatik disebut juga aspek semantik. Aspek semantik adalah hubungan antara unsur yang hadir dan unsur yang tak hadir 
dalam teks. Dalam analisis ini dibedakan dua jenis semantik, yaitu formal dan substansial. Bagian formal dari aspek semantik menjawab pertanyaan: bagaimana teks mengemukakan makna. Sementara, bagian substansial dari aspek semantik menjawab pertanyaan: apa maknanya. Penggunaan metode analisis tokoh dan analisis aspek ruang dan waktu (latar) dapat digunakan untuk mencari makna.

\subsection{Aspek Pragmatik (Verbal)}

Pembahasan pragmatik berkaitan dengan pembahasan komunikasi yang tampak dalam karya, yaitu aspek pengujarannya. Banyak hal yang dapat dibicarakan berkaitan dengan aspek pragmatik, misalnya soal pencerita (narrator) dengan penceritaannya, sudut pandang, majas atau gaya bahasa, dan sebagainya.

\section{METODE PENELITIAN}

Penelitian ini merupakan penelitian dengan metode analisis deskriptif. Metode deskriptif analisis dilakukan dengan cara mendeskripsikan fakta-fakta yang kemudian disusul dengan analisis. Secara etimologis deskripsi dan analisis berarti menguraikan. Meskipun demikian, analisis yang berasal dari Bahasa Yunani, analyein ('ana'=atas, 'lyein'=lepas, urai), telah diberikan arti tambahan, tidak semata-mata menguraikan melainkan juga memberikan pemahaman dan penjelasan secukupnya.

Setelah penetapan permasalahan, penelitian dilanjutkan dengan pengumpulan data, berupa data pustaka. Data yang dimaksud adalah berupa teks lakon Sugawara Denju Tenarai Kagami yang telah diterjemahkan ke dalam bahasa Inggris dengan judul Sugawara and the Secrets of Calligraphy, serta data penunjang lainnya.

Sesuai dengan penggunaan teori tiga aspek naratif yang dikemukaan oleh Tzvetan Todorov, langkah pertama yang dilakukan adalah pembahasan aspek sintaksis, yaitu menganalisis struktur cerita yang bertujuan mendapatkan susunan teks. Analisis aktan dan fungsi digunakan pada langkah ini. Analisis aktan dan fungsi merupakan analisis alur cerita yang didasari hubungan antaraktan. Pada langkah ini, proses dilakukan melalui pembacaan yang berulang terhadap teks lakon.
Langkah yang berikutnya yaitu pembahasan aspek semantik, yang berkaitan dengan makna dan lambang. Pada aspek ini, pembahasan dititikberatkan pada penelitian mengenai tokoh dan latar. Tokoh-tokoh yang dianalisis merupakan tokoh-tokoh utama yang menggerakkan jalan cerita pada lakon ini. Melalui analisis ini, karakter maupun sifat para tokoh tergambar melalui dialog dan tindakan yang mereka lakukan. Pembahasan karakter dan sifat-sifat yang dominan dari para tokoh ini kemudian akan mengkerucut pada penggambaran tema besar lakon ini.

Langkah selanjutnya adalah pembahasan aspek verbal/pragmatik, yang berkaitan dengan analisis sarana-sarana seperti penceritaan, sudut pandang, gaya bahasa, dan sebagainya. Pembahasan aspek pragmatik/verbal berkaitan dengan pembahasan komunikasi yang tampak dalam karya. Oleh karena itu, pada langkah ini, analisis dilakukan dengan cara mengambil kutipan-kutipan dialog ataupun ujaran yang disampaikan oleh beberapa tokoh utama pada lakon ini untuk kemudian diinterpretasikan, hingga ditemukannya nilai-nilai kehidupan yang menjadi tujuan penelitian ini.

\section{ANALISIS TIGA ASPEK NARATIF PADA LAKON SUGAWARA DENJU TENARAI KAGAMI}

\subsection{Analisis Aspek Sintaksis}

Aspek sintaksis atau hubungan in praesentia digunakan untuk menganalisis alur cerita. Analisis struktur cerita yang bertujuan mendapatkan susunan teks. Alur cerita Sugawara Denju Tenarai Kagami dianalisis berdasarkan teori sintaksis atau hubungan in praesentia. Analisis aktan dan fungsi digunakan di sini.

Analisis aktan dan fungsi akan dilakukan terhadap enam orang tokoh, yaitu Takebe Genzo, Sakuramaru, Umeomaru, Matsuomaru, Sugawara Michizane, dan Fujiwara Shihei. Berikut ini adalah salah satu contoh analisis aktan dan fungsi pada tokoh Takebe Genzo.

\section{a. Skema Naratif Aktansial Takebe Genzo}

Takebe Genzo adalah mantan bawahan Sugawara. Meskipun Sugawara telah memutuskan hubungan atasan bawahan dengan Takebe Genzo, namun Sugawara tetap mempertimbangkan Takebe Genzo sebagai salah satu kandidat pewaris ilmu kaligrafi 
Sugawara. Setelah menjalani sejumlah serangkaian ujian, akhirnya Sugawara memutuskan untuk memilih Takebe Genzo sebagai orang yang tepat untuk menerima rahasia ilmu kaligrafinya. Sebenarnya Takebe Genzo menolak keputusan Sugawara tersebut dan mengatakan bahwa ia lebih memilih untuk dapat kembali mengabdi kepada Sugawara.

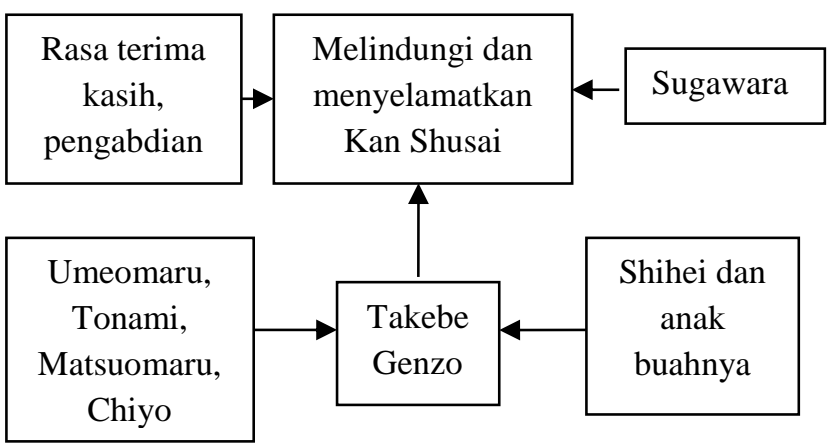

\section{Gambar 1. Skema naratif aktansial Takebe Genzo}

Namun permintaan Takebe Genzo tersebut ditolak oleh Sugawara. Selanjutnya, Takebe Genzo (subjek) yang merasa berhutang budi atas kebaikan hati Sugawara (pengirim), yang memilih Takebe Genzo untuk menjadi pewaris ilmunya, berusaha untuk membantu Sugawara yang difitnah oleh Shihei (penentang 1) dengan bantuan Tonami, istrinya (penolong). Takebe Genzo menyelamatkan anak lelaki satu-satunya Sugawara yang bernama Kan Shusai (objek), dan menyamarkannya sebagai anak kandungnya bersama dengan Tonami. Dalam pelariannya, Takebe Genzo mendirikan sekolah kaligrafi untuk anak-anak di daerah yang terpencil. Namun persembunyiannya tersebut kemudian diketahui oleh anak buah Shihei (penentang 2) yang memaksanya untuk memenggal kepala Kan Shusai untuk dipersembahkan kepada Shihei. Takebe Genzo kemudian menggunakan salah seorang anak muridnya untuk dipenggal menggantikan kepala Kan Shusai. Pada akhirnya anak buah Shihei terkecoh dan siasat Takebe Genzo untuk menyelamatkan Kan Shusai berhasil. Skema naratif aktansial dari tokoh Takebe Genzo dapat dilihat pada gambar 1 diatas.

\section{b. Skema Naratif Fungsional Takebe Genzo}

1. Situasi Awal

Takebe Genzo terpilih menjadi pewaris rahasia ilmu kaligrafi Sugawara.

2. Proses Kualifikasi atau Tahap Awal
Berita tentang penjatuhan hukuman pengasingan kepada Sugawara ke Tsukushi.

3. Proses Penentuan atau Tahap Utama

Takebe Genzo menyelamatkan Kan Shusai dari kediaman Sugawara yang telah dikepung oleh anak buah Shihei. Ia dibantu oleh Tonami, istrinya, dan Umeomaru. Usaha penyelamatannya ini dipergoki oleh anak buah Shihei yang bernama Arashima Chikara. Takebe Genzo kemudian berduel dengan Arashima Chikara yang diakhiri dengan kematian Arashima. Takebe Genzo kemudian melarikan diri ke sebuah daerah terpencil dan mendirikan sekolah kaligrafi untuk anak-anak.

4. Proses Kegemilangan atau Tahap Sanksi Tempat persembunyian Takebe Genzo, Tonami dan Kan Shusai diketahui oleh anak buah Shihei.Kediamannya telah dikepung oleh anak buah Shihei dan Takebe Genzo diperintahkan untuk menyerahkan kepala Kan Shusai. Dalam kebingungannya, Takebe Genzo mendapatkan ide untuk menggunakan salah seorang anak muridnya untuk dipenggal menggantikan Kan Shusai. Meskipun di dalam hatinya ia merasa berat dan tidak tega untuk melakukannya, ia tetap menjalankan siasatnya tersebut. Namun, ia meneguhkan hati mereka demi pengabdian dan kesetiannya kepada Sugawara. Siasatnya berhasil mengecohkan Matsuomaru, anak buah Shihei, yang ditugaskan untuk mengenali kepala Kan Shusai.

5. Situasi Akhir

Takebe Genzo berhasil menyelamatkan Kan Shusai lolos dari maut. Dengan terselamatkannya Kan Shusai, maka Takebe Genzo telah berhasil mencegah berakhirnya garis keturunan Sugawara.

Berdasarkan hasil analisis pada enam tokoh tersebut, lakon Sugawara Denju Tenarai Kagami memiliki alur cerita yang didasari oleh hubungan antaraktan dan keinginan aktan-aktan untuk mengabdi dan menunjukkan kesetiaan kepada atasannya.

\subsection{Analisis Aspek Semantik}

Tokoh (actor), menurut Greimas, adalah apa saja, baik individu, antropomorfis, zoomorfis, maupun kelompok pada level diskursif dalam cerita. Tokoh mengacu kepada unsur figuratif yang konkret.

Menganalisis tokoh adalah bagian dari analisis semantik, yang merupakan kelanjutan dari analisis sintaksis. Todorov menyebut analisis semantik dengan analisis in absentia. Aspek semantik 
(hubungan in absentia atau hubungan paradigmatic) adalah hubungan antara unsur yang hadir dengan yang tak hadir dalam teks. Dalam hal ini aspek semantik memiliki dua bagian, yaitu formal dan substansial. Bagian formal dari aspek semantik menjawab pertanyaan bagaimana teks mengemukakan makna. Bagian substansial dari aspek semantik menjawab pertanyaan apakah maknanya. Dalam penelitian ini, pencarian makna akan dilakukan melalui analisis tokoh.

\section{Analisis Tokoh}

\section{1) Sugawara, Loyal, Tegas dan Teguh pada Prinsip}

Sugawara atau yang dikenal sebagai nama Kan Shojo, sebagai panggilan kehormatan, duduk di pemerintahan kekaisaran sebagai Menteri Kanan. Selain pengetahuannya yang tinggi dalam bidang kesusastraan dan ilmu kaligrafi, pribadinya yang bijaksana membuat pertimbangannya selalu didengar oleh Kaisar. Kedudukannya yang setingkat dengan Fujiwara Shihei, seringkali membuat Shihei iri padanya karena perhatian Kaisar pada Sugawara.

Sugawara selalu menjalankan tugas yang diperintahkan oleh Kaisar kepadanya dengan sebaik-baiknya. Ia juga merupakan pribadi yang tegas dan teguh dalam memegang prinsip. Selain itu ia adalah pribadi yang dermawan.

Berikut ini adalah beberapa contoh kutipan-kutipan dialognya:

a. Umeomaru: "Pandangannya tidak sesempit pandanganmu. Aku tahu betul betapa dermawannya ia. .... semua adalah karena Tuan Sugawara membantu ketika mendengar ayah kita meratapi kesulitannya dalam membesarkan anak-anaknya..... Kita pun bahkan diberi gaji. Ayah kita, Shirokuro, sekarang hidup nyaman di lahan yang dihadiahkan kepadanya di Sata... “"

Berikut ini adalah kutipan antara dialog Sugawara dengan Nyonya Sugawara:

b. Sugawara: "Jangan buat dirimu tampak bodoh. Meskipun tuduhan terhadap diriku adalah salah, namun aku tidak memendam kebencian kepada Kaisar. Perintah Kaisar bahwa aku harus menurunkan keahlian kaligrafiku, karena usiaku yang semakin tua, adalah merupakan perhargaan Kaisar... "

Berikut ini adalah kutipan perkataan Sugawara kepada Umeomaru: c. Sugawara: "Tunggu Umeo, Kau kurang ajar. Michizane menjadi seperti ini adalah karena perintah Kaisar. Di samping tindakan Mareyo, siapapun yang melawan Kaisar berarti ia telah menghina Kaisar. Siapapun orang-orang yang berada di dalam kediamanku, yang tidak patuh dengan peraturanku, maka ia akan dibuang selamanya. Dan itu juga termasuk kau Umeo!" Sifatnya yang lurus, setia dan patuh pada perintah Kaisar, digambarkan ketika ia tidak memrotes sama sekali keputusan Kaisar yang menjatuhinya hukuman pengasingan ke Tsukushi.

\section{2) Sakuramaru, Ketulusan, Penyesalan, dan Kesetiaan sampai Mati}

Sakuramaru adalah salah seorang dari tiga bersaudara kembar, anak dari Shiradayu. Majikannya adalah Pangeran Tokiyo. Sakuramaru bertugas untuk mengurus kereta yang digunakan oleh Pangeran Tokiyo. Ia adalah seorang yang berhati lembut dan perhatian. Sakuramaru yang mengetahui bahwa Pangeran Tokiyo menjalin hubungan dengan Putri Kariya, anak angkat Sugawara, membuat rencana rahasia bersama istrinya, Yae, untuk mempertemukan sepasang kekasih ini di tepi sungai Kamo. Namun rencananya ini membawa melapetaka bagi Pangeran Tokiyo, dan Sugawara. Skandal tersebut dijadikan Shihei, musuh Sugawara di istana, sebagai fitnah untuk menghancurkan Sugawara dan keluarganya. Merasa menyesal atas peristiwa tersebut, akhirnya Sakuramaru memutuskan untuk mengakhiri hidupnya dengan melakukan bunuh diri untuk menebus rasa bersalahnya pada Pangeran Tokiyo dan Sugawara, dan untuk membuktikan kesetiaan hatinya dan kehormatan dirinya.

Berikut ini adalah contoh kutipan penyataanpernyataan Sakuramaru:

a. Sakuramaru: "Awalnya, Tuanku, aku hanyalah anak lelaki dari seorang petani yang kotor. Merupakan kebaikan hati Tuan Sugawaralah bahwa aku menerima gaji dan menjadi salah seorang pelayanmu. Aku tidak dapat berdiri tanpa malu dan melihat orang yang telah banyak berjasa padaku dikirim ke tempat pengasingan. Dan terlebih, tidak ada yang dapat aku lakukan...."

b. Sakuramaru: “...Aku mungkin hanya orang rendahan, tetapi aku memiliki rasa kehormatan dan dalam kematian akan aku buktikan kesetiaanku." 


\section{3) Umeomaru, Pribadi yang Lurus, Setia dan Mengabdi}

Umeomaru adalah saudara kembar dari Sakuramaru. Ia mengabdi pada keluarga Sugawara. Ia seorang yang patuh dan setia pada atasannya. Ia digambarkan sebagai orang yang berpikiran pendek karena emosinya yang cukup tinggi. Ketika berita hukuman pengasingan Sugawara terdengar olehnya, ia berusaha untuk menyelamatkan keluarga Sugawara. Setelah ia merasa tidak ada yang dapat ia lakukan di ibukota, ia pun meminta ijin ayahnya, Shiradayu, untuk diperbolehkan menyusul Sugawara di tempat pengasingannya untuk melayani dan mengabdikan dirinya. Namun Shiradayu menyuruhnya untuk mencari keberadaan Nyonya Sugawara dan memastikan keselamatannya.

Berikut ini adalah kutipan-kutipan dialog mengenai sifat-sifat Umeomaru:

a. Umeomaru: "Ya, betul. Tidak seperti kediamannya yang nyaman di ibukota, tempat tinggalnya yang sekarang di Tsukushi hanyalah sebuah pondok yang sederhana. Ia tidak punya orang untuk melayani urusannya, jadi aku, Umeomaru, memohon untuk pergi dan melayani beliau. Aku mohon ijinmu untuk pergi."

\section{4) Matsuomaru, Dilema pada Dua Kesetiaan}

Matsuomaru adalah saudara kembar dari Sakuramaru dan Umeomaru. Ia adalah seorang yang kasar dan temperamental. Majikannya adalah Fujiwara Shihei, yang menjabat sebagai Menteri Kiri. Tokoh Matsuomaru ini digambarkan sebagai tokoh yang mengalami dilema pada dua kesetiaan. Sebagai orang yang mengabdi kepada majikannya, Shihei, ia berkewajiban untuk menunjukkan kesetiaan kepada atasannya, namun di sisi lain Matsuomaru juga merasa berutang budi kepada Sugawara karena Sugawara telah banyak menolong ayah Matsuomaru di masa lalu yang mengalami kesulitan keuangan dalam membesarkan ketiga anak kembarnya. Di posisinya sebagai pengikut Shihei, ayahnya menganggap Matsuomaru sebagai orang yang tidak tahu balas budi karena membela Shihei, orang yang telah menyebabkan Sugawara dikenakan hukuman pengasingan. Terlebih di saat Matsuomaru memohon untuk dapat memutuskan hubungan darah dengan keluarganya agar ia dapat leluasa menunjukkan kesetiannya pada Shihei. Atas keputusannya tersebut, ia dicap sebagai musuh oleh ayah dan saudara kandungnya.
Di balik sosoknya yang digambarkan sebagai orang kasar dan tidak berperasaan, ternyata di dalam hatinya ia tetap menyimpan rasa hutang budi pada Sugawara, hingga pada suatu saat ia membuat rencana untuk menebus segala kesalahannya pada Sugawara dan keluarganya. Untuk memuluskan rencananya, ia berpura-pura sakit keras dan memohon kepada Shihei untuk pensiun dan mengakhiri hubungan atasan bawahan dengan Shihei dengan alasan kesehatannya yang terus memburuk. Ia juga mengorbankan anak lelaki satusatunya untuk dapat menyelamatkan anak lelaki Sugawara yang bernama Kan Shusai. Dengan cara demikian ia berharap ia dapat membayar hutang budinya kepada Sugawara. Selama ini ia merasa malu atas prasangka orang yang menganggap dirinya tidak punya hati nurani. Berikut ini adalah kutipan-kutipan dialognya:

a. Matsuomaru: "Aku ucapkan terima kasih. Karena kau telah mengijinkannya, tanpa basabasi lagi, aku bermaksud untuk memutuskan hubungan keluarga. Aku rasa kau telah menduga bahwa aku melakukan ini adalah demi kesetiaanku pada Tuanku Shihei”.

b. Matsuomaru: “...Tuan Sugawara tahu apa yang sebenarnya ada dalam hatiku. "Mengapa pinus tetap kokoh berdiri tanpa perasaan?" tulisnya. Dan yang lainnya yang membaca puisi itu mengartikan bahwa Matsuo tidak punya perasaan, bersikap masa bodoh, dan aku harus menanggung rasa malu. Kasihanilah aku Genzo...”.

\section{5) Takebe Genzo, Dilema antara Hutang Budi dan Perasaan Kemanusiaan}

Genzo adalah mantan pengikut Sugawara yang kemudian diusir oleh Sugawara karena menjalin cinta dengan Tonami, salah seorang pelayan wanita di kediaman Sugawara. Ia adalah murid Sugawara yang memiliki ketertarikan yang mendalam dan kemampuan yang tinggi dalam bidang ilmu kaligrafi. Genzo digambarkan sebagai tokoh yang mempunyai hati nurani dan mau mengakui kesalahan, dan setia kepada Sugawara, walaupun Sugawara telah memutuskan hubungan atasanbawahan dengannya karena kesalahan Takebe Genzo sendiri. Takebe Genzo yang menyadari betul kesalahannya tersebut memohon kepada Sugawara agar hubungan atasan-bawahan yang telah terjalin dahulu dapat kembali seperti semula. Namun Sugawara tidak berkenan. Sebagai mantan pengikut Sugawara, Takebe Genzo digambarkan mati-matian mempertaruhkan nyawanya untuk menyelamatkan Kan Shusai, anak lelaki Sugawara satu-satunya, 
dari kejaran orang-orang Shihei sebagai bentuk kesetiaannya kepada Sugawara. Genzo menduga bahwa apa yang menimpa Sugawara merupakan skenario jahat dari Shihei yang ingin melenyapkan seluruh keluarga Sugawara. Dan pada klimaksnya, Genzo, dengan bantuan istrinya yang bernama Tonami, terpaksa memenggal kepala salah seorang muridnya yang diakuinya sebagai kepala Kan Shusai, sebagai kamuflase untuk menyelamatkan satu-satunya penerus keluarga Sugawara tersebut. Berikut ini adalah kutipan dialog antara Takebe Genzo dengan istrinya, Tonami:

a. Genzo: "...Nanti jika kita berhasil mengelabui Matsuomaru dengan menggunakan anak tersebut untuk menggantikan Kan Shusai, kita akan pergi melarikan diri dan membawa tuan muda langsung ke kediaman bibi Tuan Sugawara di Kawachi. Tapi untuk sementara waktu, situasi akan tidak menentu."

b. Genzo: "Hentikan! Kita tidak bisa menukar hidup Kan Shusai dengan apapun. Kau tahu itu demi tuan kita!"

Tonami: "Ya, kau benar. Kalau kita berlemah hati, kita akan gagal. Kita harus tidak berbelas kasih."

Perpaduan tokoh-tokoh dalam lakon Sugawara Denju Tenarai Kagami menampakkan adanya dua hal yang dominan yang hendak disampaikan pada lakon tersebut, yaitu prinsip kesetiaan (loyalitas) dan pengabdian. Tokoh Sugawara merupakan sosok yang teguh pada prinsip, patuh, dan setia kepada Kaisar. Tokoh Umeomaru digambarkan bersifat setia dan mengabdi kepada tuannya, Sugawara. Ia terus berupaya melakukan apapun yang dapat dilakukannya untuk dapat berkontribusi dalam penyelamatan keluarga Sugawara dari rencana jahat Shihei dan anak buahnya. Sementara itu, tokoh Sakuramaru memperlihatkan gagasan mengenai kesetiaan yang ditunjukkan dengan tindakan bunuh diri untuk menjaga kehormatan dirinya. Tokoh Matsuomaru digambarkan sebagai sosok yang dingin, tidak berperasaan, kasar, dan tidak tahu balas budi. Ia rela untuk memutuskan tali persaudaraan dengan ayah dan saudara-saudara kembarnya demi kesetiannya pada Shihei. Selain itu, Matsuomaru dengan terang-terangan menegaskan keberpihakannya pada Shihei dan berseberangan dengan ayah dan kedua saudara kembarnya. Namun di akhir cerita, sisi kesadaran dan manusiawi pada diri Matsuomaru muncul. Pada setiap tokoh diperlihatkan gagasan tentang kesetiaan dan pengabdian yang dilakukan dengan cara mereka masing-masing.

\subsection{Analisis Aspek Pragmatik (Verbal)}

Dalam analisis pragmatik (verbal), akan dibahas mengenai aspek ujaran dari beberapa tokoh dalam lakon Sugawara Denju Tenarai Kagami, yang bertujuan untuk mengetahui tema dan nilai kehidupan dalam lakon ini. Dari sejumlah adegan yang ditampilkan, tindakan kesetiaan dan pengabdian yang dilakukan oleh tokoh-tokoh utama dalam lakon ini berpangkal dari hutang budi (on) yang pernah diterima oleh tokoh-tokoh tersebut. Konsep pengembalian hutang budi ini dalam kebudayaan Jepang disebut sebagai ongaeshi. Seseorang yang pernah menerima budi baik, berkewajiban untuk mengembalikan kebaikan tersebut kepada si pemberi. Dengan demikian, si penerima menanggung giri (kewajiban sosial) seumur hidupnya kepada si pemberi.

Befu (1971: 168-169) mengatakan giri secara harfiah dapat diartikan sebagai "kewajiban sosial", yaitu sebuah kewajiban yang bersifat etis dan moral yang mengharuskan orang Jepang untuk bersikap seperti yang diharapkan oleh masyarakat dalam berhubungan dengan individu-individu lain, dengan siapa orang menjalin hubungan yang istimewa atau khusus.

Berikut ini adalah salah satu contoh pernyataan hutang budi 3 tokoh kembar tiga Sakuramaru, Umeomaru, dan Matsuomaru kepada tokoh Sugawara.

a. Umeomaru: "Wajah dan hati kita mungkin berbeda satu sama lain, namun kita bertiga mengenakan pakaian yang sama. Semua karena pertolongan Tuan Sugawara yang mendengar ketika ayah kita mengalami kesulitan dalam membesarkan kita, anak-anaknya. ......Kita berhutang budi kepada Tuan Sugawara, yang menjadi ayah pelindung kita. Kita mungkin saja mengabdi pada 'rumah' yang berbeda, namun kita sama sekali tidak boleh memandang rendah Tuan Sugawara."

Pada satu contoh kutipan ujaran yang disampaikan oleh Umeomaru di atas, didapatkan gambaran bahwa tokoh kembar tiga tersebut memiliki hutang budi kepada tokoh Sugawara karena Sugawara pernah menolong ayah mereka ketika dulu mengalami kesulitan dalam membesarkan tiga anak kembar sekaligus. Selain itu berkat bantuan Sugawara, Sakuramaru, Umeomaru, Matsuomaru 
dapat masuk ke dalam lingkungan istana dan dipekerjakan sebagai pelayan (pengurus kereta).

Dalam budaya Jepang, hutang budi atau jasa yang pernah diterima seseorang disebut sebagai on. Adanya on atau hutang budi yang seseorang dapatkan dari orang lain di masa lalu, menjadikan ia senantiasa ingat akan kewajiban mengembalikan on yang harus dipenuhinya di masa depan sebagai timbal balik dari jasa yang pernah diterimanya. Konsep on merupakan dasar moralitas orang Jepang pada tingkat yang melibatkan rasa bersalah yang mendalam dan rasa berterima kasih. Hal ini jelas tergambar pada ujaran ketiga tokoh di atas. Konsep on ini pulalah yang menggerakkan cerita pada lakon ini.

Selain ketiga tokoh di atas, tokoh Takebe Genzo juga merupakan tokoh yang memiliki hutang budi kepada tokoh Sugawara, seperti yang terungkap pada kutipan dialog di bawah ini.

b. Genzo: "Terima kasih, aku sangat berhutang budi. Sekarang, karena rahasia kaligrafi itu diturunkan pada saya, apakah berarti kesalahanku juga dimaafkan dan dapat memanggilmu sebagai tuanku seperti sediakala?"

Bagi Takebe Genzo, dengan berakhirnya hubungan atasan-bawahan dengan Sugawara bukan berarti bahwa kewajiban pengembalian budi baik kepada Sugawara turut berakhir pula, karena ternyata Sugawara masih menaruh kepercayaan kepada Genzo untuk dijadikan sebagai pewaris rahasia ilmu kaligrafinya. Mendapat kepercayaan yang begitu besar dari Sugawara, membuat Genzo semakin terikat dengan kebaikan Sugawara tersebut.

Seperti yang telah dipaparkan di atas, tokoh Sakuramaru, Matsuomaru, Umeomaru, dan Takebe Genzo menerima on dari tokoh Sugawara. Dalam hubungan on, sekali terjadi pemberian dan penerimaan maka akan "memaksa" penerima untuk membayar kembali untuk mengembalikan keseimbangan. Ongaeshi berarti pembayaran kembali on, dan onjin berarti pemberi on, keduanya adalah salah satu yang paling umum digunakan dalam kosakata bahasa Jepang. Dalam etika Konfusianisme, nilai moral satu-satunya adalah apa yang telah ditetapkan sebagai kewajiban sosial. Pelaksanaan kewajiban sosial dinilai sebagai suatu "kebaikan" yang utama, sedangkan penyimpangan dan ketidakpatuhan pada kode etik yang telah ditetapkan dinilai sebagai suatu "kejahatan".

Sebagai konsekuensi atas penerimaan on dari tokoh Sugawara, maka keempat tersebut berkewajiban untuk mengembalikan utang budi atau jasa yang pernah mereka terima. Penerima on diharapkan untuk sadar dan merasa berterima kasih pada pemberi on. Rasa berterima kasih yang tinggi berpaut dengan on boleh jadi menjadi dasar karakter moral orang Jepang. Rasa terima kasih daat diekspresikan secara lisan dan bahkan diwujudkan dengan tindakan pengembalian. Tindakan melupakan bahwa pernah menerima on atau menolak untuk membayar kembali uang, akan memunculkan tuduhan onshirazu yang berarti tidak sadar on atau tidak tahu terima kasih.

Berikut ini adalah kutipan mengenai tindakan atau langkah yang diambil oleh para tokoh dalam mengembalikan on (ongaeshi) kepada tokoh Sugawara.

Tokoh Sakuramaru yang merasa bersalah atas fitnah yang menimpa Pangeran Tokiyo dan Sugawara memutuskan untuk mengakhiri hidupnya dengan melakukan bunuh diri sebagai bentuk perwujudan kesetiaannya, seperti yang terdapat dalam ujaran Sakuramaru berikut ini:

c. Sakuramaru: “...Aku mungkin hanya orang rendahan, tetapi aku memiliki rasa kehormatan dan dengan kematian akan aku buktikan kesetiaanku."

Kegagalan seorang tokoh dalam melaksanakan giri (kewajiban sosial) umumnya ditebus dengan melakukan bunuh diri. Hal ini juga terjadi pada tokoh Sakuramaru. Untuk menebus ketidakberdayaannya dalam membantu Sugawara dan menunjukkan pengabdiannya pada Pangeran Tokiyo, ia mengakhiri hidupnya. Bunuh diri merupakan cara menjaga kehormatan diri daripada ia harus hidup menanggung malu. Perasaan malu dan rasa bersalah yang dirasakan oleh Sakuramaru adalah karena ia gagal menjaga nama baik tuannya dan ia melakukan kesalahan dalam mengambil keputusan karena ia merencanakan pertemuan rahasia antara sepasang kekasih, Pangeran Tokiyo dan Putri Kariya, yang berujung pada pencemaran nama baik Pangeran Tokiyo dan pengasingan Sugawara. 
Seorang samurai wajib menjaga dengan baik reputasinya. Ini menuntutnya untuk menghindari aib dan menjalankan nilai-nilai kesopanan serta membersihkan namanya dari penghinaan. Konsep giri semakin dekat pada harga diri dan kehormatan diri. Pemenuhan terbaik giri adalah pengorbanan hidup, sedangkan aib terbesar adalah mati dalam keadaan tidak terhormat. Oleh karena itu, seorang samurai harus selalu mempersiapkan mentalnya untuk menemui kematiannya kapanpun dengan berani dan tepat.

Kewajiban sosial dalam pengembalian hutang budi tidak terkandung dalam pengertian kewajiban terhadap masyarakat dalam lingkup luas, melainkan terhadap unit sosial tempat ia tergabung. Kelompok tempat seseorang menyerahkan kesetiaannya merupakan sebuah unit sosial yang dikenal dengan sebutan "ie" atau "rumah". Selama zaman Edo, struktur politik Jepang secara teoretis terdiri atas sejumlah $i e$, yang para pemimpinnya, yang disebut dengan kachou, menyerahkan kesetiaanya kepada shogun, sebagai penguasa tertinggi. Dalam sebuah ie, seluruh anggota memberikan kesetiaan dan kepatuhan yang tidak perlu diragukan lagi kepada pemimpinnya (Ernst, 1974:226). Karena ie merupakan unit sosial yang paling utama, penjagaan ie oleh para anggotanya merupakan sesuatu yang paling penting meskipun hal tersebut berarti menghendaki pengorbanan yang besar. Kesetiaan kepada ie merupakan "kebaikan" tertinggi yang dapat dicapai oleh para anggotanya.

Hal ini tergambar pada tokoh Umeomaru dan Takebe Genzo, yang merupakan anggota dari ie yang dipimpin oleh Sugawara. Dengan menerima gaji dari tuannya, yaitu Sugawara, berarti memunculkan kewajiban bagi Umeomaru dau Takebe Genzo untuk mengabdikan seluruh hidupnya untuk melayani tuannya. Berikut adalah kutipan penyataan Umeomaru.

d. Umeomaru: "Ya, betul. Tidak seperti kediamannya yang nyaman di ibukota, tempat tinggalnya yang sekarang di Tsukushi hanyalah sebuah pondok yang sederhana. Ia tidak punya orang untuk melayani urusannya, jadi aku, Umeomaru, memohon untuk pergi dan melayani beliau. Aku mohon ijinmu untuk pergi."

Konfusianisme menetapkan dasar ideologi untuk mengikat hubungan atasan dan bawahan melalui konsep tugas dan kewajiban, dan menjadikan pengorbanan diri demi atasan sebagai sikap utama bagi seorang samurai. Seorang samurai dianggap berhutang seumur hidup kepada tuannya sebagaipengembalian atas gaji yang selama ini menopan hidupnya. Oleh karena itu seorang samurai wajib membalasnya dengan pengabdian dan kesetiaan yang mutlak.

Merupakan sebuah tugas pula bagi seorang samurai untuk menjalani penderitaan dan pengorbanan untuk menghormati kepercayaan yang telah diberikan atasannya atau untuk membalas kebaikan tuannya. Penderitaan dan pengorbanan yang harus dilalui oleh Takebe Genzo bersama istrinya, Tonami, yang harus hidup dalam bahaya di bawah pengejaran anak buah Shihei karena mereka berdua menyembunyikan anak lelaki Sugawara yang bernama Kan Shusai. Berikut adalah kutipan dialog antara Takebe Genzo dan Umeomaru yang menggambarkan hal tersebut.

e. Genzo: “...Tuan Sugawara sangat menjaga aturan. Aku khawatir ada orang-orang yang memfitnah tuan kita dan merencanakan penghancuran seluruh keluarga Sugawara. Dengarkan rencanaku, Umeo. Percayakan tuan muda Kan Shusai padaku dan istriku...Kami akan membawanya pergi secepat mungkin. Aku mohon."

Umeomaru: "Ini tuan muda kita yang sangat berharga, Genzo. Jangan sampai ia terluka."

Genzo: "Aku paham, aku akan menjaganya."

Meskipun pada dasarnya Takebe Genzo sudah tidak lagi berada di bawah ie yang dipimpin oleh Sugawara, namun Takebe Genzo tetap merasa terikat seumur hidupnya oleh kebaikan yang pernah diterimanya dari Sugawara. Pada masa Tokugawa, ketika hubungan antara atasan dan bawahan diberlakukan secara ketat, giri dinilai sebagai kebaikan samurai yang tertinggi atau terpenting. Para samurai percaya bahwa menjalankan giri adalah tanggung jawab mereka yang utama.

Sebagai pengurus kereta Shihei, tokoh Matsuomaru terikat giri dengan Shihei, karena ia mendapat upah dari Shihei dan berada di bawah ie yang dipimpin oleh Shihei. Di sisi lain, ia tidak dapat berpaling bahwa ia pun terikat giri dengan Sugawara di masa lalunya. Sebagai bagian dari sebuah ie, Matsuomaru pun dituntut untuk memberikan kesetiaan dan kepatuhan yang mutlak kepada pemimpinnya. Untuk menjalankan girinya tersebut ia memutuskan hubungan darah dengan ayah dan 
saudara-saudara kembarnya, seperti yang tergambar dalam kutipan berikut ini.

f. Matsuomaru: "Karena kau telah mengijinkannya, tanpa basa-basi lagi, aku ber"maksud untuk memutuskan hubungan keluarga. Aku rasa kau telah menduga bahwa aku melakukan ini adalah demi kesetiaanku pada Tuanku Shihei."

Namun ternyata Matsuomaru tak dapat membohongi hati kecilnya bahwa ia pun berhutang budi pada Sugawara. Seperti yang telah dikemukakan di atas, tindakan melupakan bahwa pernah menerima on atau menolak untuk membayar kembali utang budi, akan memunculkan tuduhan onshirazu yang berarti tidak sadar on atau tidak tahu terima kasih. Hal ini pulalah yang dialami oleh tokoh Matsuomaru seperti yang tergambar dalam ujaran berikut ini.

g. Matsuomaru: “... Tuan Sugawara tahu apa yang sebenarnya ada dalam hatiku. "Mengapa pinus tetap kokoh berdiri tanpa perasaan?" tulisnya. Dan yang lainnya yang membaca puisi itu mengartikan bahwa Matsuo tidak punya perasaan, bersikap masa bodoh, dan aku harus menanggung rasa malu. Kasihanilah aku Genzo....Potongan puisi "mengapa pinus tetap kokoh berdiri tanpa perasaan?" yang dibuat oleh Sugawara mengandung sindiran halus bagi Matsuomaru, yang membuat Matsuomaru merasa malu. Kata 'pinus' pada puisi tersebut mengacu pada kata 'matsu' yang berarti pinus, yang merupakan nama dari Matsuomaru. Puisi ini menggambarkan perasaan Sugawara terhadap Matsuomaru, yang menyiratkan kesedihan hati Sugawara karena hati Matsuomaru tidak tergerak sedikitpun atas prahara yang menimpa Sugawara dan keluarganya."

Matsuomaru paham betul bahwa ia tetap terikat giri dengan Sugawara. Oleh karena itu ia pun mencari cara dan kesempatan yang tepat untuk dapat membayar hutang budi yang pernah diterimanya dari Sugawara, seperti yang tergambar dalam kutipan berikut ini.

Matsuomaru: Aku berpikir bahwa sekaranglah saat untuk membayar hutang terima kasihku pada Tuan Sugawara. Aku membicarakan masalah ini dengan Chiyo, istriku, dan kami memutuskan untuk mengirim Kotaro, anak lelaki kami satu-satunya. Ia akan menjadi pengganti.

Dari pembahasan di atas, keempat tokoh, yaitu Sakuramaru, Umeomaru, Tekebe Genzo, dan Matsuomaru, melakukan beragam upaya untuk dapat membalas hutang budi kepada tokoh Sugawara. Namun bagaimanapun juga, on tidak selalu mendatangkan respons yang positif. On seringkali dinilai sebagai beban berat yang ingin disingkirkan sesegera mungkin. Menerima on dapat berarti kehilangan kebebasan. Aspek yang memberatkan dari on diekspresikan sebagai giri.

Dalam pelaksanaan giri, umumnya seseorang mengalami dilema. Tak jarang dilema muncul karena kewajiban sosial yang harus dilakukannya bertentangan dengan keinginan pribadinya. Keinginan pribadi atau perasaan manusiawi inilah yang disebut dengan ninjo. Apabila giri merupakan sesuatu yang bersifat moral dan sosial, maka ninjo bersifat psikologis dan personal atau pribadi (Befu, 1971: 169).

Pertentangan antara kewajiban menjalankan giri dan perasaan manusiawi (ninjo) terlihat dominan pada 3 tokoh, yaitu Sakuramaru, Takebe Genzo dan Matsuomaru. Berikut ini adalah contoh kutipan dialog dan ujaran yang menggambarkan suasana batin yang dialami oleh masing-masing tokoh dalam menanggung giri.

h. Sakuramaru: "Kau dengar ia, istriku tersayang? Yang sangat berharga baginya adalah hidupku yang membuatnya penuh dengan kecemasan. Untuk melibatkanmu dalam kematianku, tanpa membalas seluruh kebaikanmu, oh ayah, maafkanlah anakmu yang tak berbakti ini! Aku mungkin terlahir sebagai orang rendahan, namun aku mempunyai rasa kehormatan, dan dengan kematian aku akan buktikan kesetiaanku."

Berdasarkan kutipan dialog di atas, tokoh Sakuramaru memilih untuk melakukan bunuh diri sebagai bukti kesetiaannya kepada Pangeran Tokiyo. Selain itu, Rasa malu dan bersalahnya pada Sugawara yang memenuhi hati Sakuramaru pulalah yang membuatnya bertekad untuk mengakhiri hidupnya. Bagi Sakuramaru, lebih baik mati daripada hidup menanggung malu. Meskipun berat untuk meninggalkan istri yang sangat dicintainya dan ayahnya yang telah renta, ia tetap pada keputusannya. Di satu sisi Sakuramaru beban giri yang ia rasakan kepada Sugawara dan Pangeran 
Tokiyo dan kegagalannya menjaga nama baik tuannya mendorongnya untuk melakukan bunuh diri sebagai bentuk kehormatan diri, walau di sisi lain perasaan manusiawinya sebagai suami dan anak laki-laki membuatnya merasa berat untuk meninggalkan istri dan ayah yang sangat disayanginya tersebut.

Contoh dilema lainnya juga terjadi pada tokoh Matsuomaru yaitu ketika ia memutuskan untuk mengirimkan anak lelaki satu-satunya yang bernama Kotaro, untuk digunakan menjadi pengganti Kan Shusai. Pengorbanannya yang demikian besar tergambar dalam beratnya kesedihan yang dialaminya sebagai seorang ayah karena harus kehilangan putra yang dicintainya demi menunaikan giri terhadap Sugawara. Hal ini tergambar dalam kutipan ujaran Matsuomaru berikut ini.

i. Matsuomaru: “...Kasihanilah diriku Genzo. Kepada orang yang akan berkata,"seseorang yang tanpa seorang anak lelakipun adalah binatang, " aku akan menjawab,"Yang paling berharga bagi seorang pria adalah anak lelakinya!"

Pertentangan batin pula dialami oleh Takebe Genzo yaitu ketika ia mengalami dilema saat ia harus memenggal salah seorang muridnya yang digunakan sebagai pengganti Kan Shusai. Perasaan sedihnya karena muridnya sudah ia anggap sebagai anaknya sendiri, namun di sisi lain ia berkewajiban untuk melindungi Kan Shusai demi girinya pada Sugawara.

Ketika pada akhirnya ia menemukan Kotaro untuk menggantikan posisi Kan Shusai, ia merasa kasihan dan tidak tega karena ia menganggap murid-muridnya sebagai anak-anaknya sendiri. Hal ini tergambar dalam kutipan dialog berikut ini:

j. Genzo: "Murid-muridku kuanggap sama seperti anak-anakku sendiri."

k. Genzo: "Tidak ada penderitaan dan kesedihan yang lebih besar daripada penderitaan orangorang rendahan yang mengabdi pada kaum bangsawan di istana."

Beratnya pelaksanaan giri berupa pembayaran kembali hutang budi, serta pertentangan batin yang muncul, dialami oleh beberapa tokoh, yaitu Takebe Genzo, Sakuramaru dan Matsuomaru. Meskipun demikian, para tokoh tersebut tetap memrioritaskan kewajiban mereka dalam menunaikan giri yang mereka emban, meski gambaran kepedihan dan kesedihan tergambar dengan jelas melalui ujaranujaran mereka.

Berbeda dengan apa yang dilakukan oleh tokoh Takebe Genzo dan Matsuomaru, pada tokoh Sakuramaru, kegagalannya dalam melaksanakan kewajiban kepada atasannya diwujudkan melalui tindakan bunuh diri. Tindakan yang dilakukannya ini merupakan bentuk tanggung jawab pribadinya dan penjagaan kehormatan diri, untuk menghindari rasa malu yang dirasakannya.

\section{KESIMPULAN DAN SARAN}

Berdasarkan hasil analisis yang terdapat pada bab sebelumnya, tema pada lakon Sugawara Denju Tenarai Kagami ini adalah mengenai kesetiaan dan pengabdian bawahan kepada atasan. Penggambaran konsep kesetiaan dan pengabdian melalui perilaku dan ujaran para tokoh dalam lakon ini didasarkan pada kesadaran dan rasa terima kasih atas budi baik atau jasa yang pernah mereka terima dari pemberi budi. Hal inilah yang mengokohkan rasa kesetiaan dan pengabdian tokoh-tokoh dalam lakon ini.

Bangsa Jepang mendefinisikan tugas tertinggi dalam hidup ini sebagai pemenuhan kewajibankewajiban seseorang. Mereka menerima kenyataan bahwa pembayaran kembali budi baik atau on, yang terkandung dalam istilah giri, berarti pengorbanan keinginan serta kesenangan pribadi (ninjo). Dengan demikian, pemenuhan kewajiban-kewajiban tersebut menjadi prioritas utama dibandingkan dilema perasaan manusiawi yang terkadang muncul dan menjadi kontra dengan pemenuhan kewajiban tersebut. Oleh karena itu, nilai kebaikan yang tertinggi dalam konsep moral orang Jepang tergambar pada kemampuannya dalam memenuhi kewajiban-kewajiban yang mereka emban. Konsep ini pulalah yang mengatur hubungan antar individu pada masyarakat Jepang, sehingga dapat dikatakan bahwa on dan giri merupakan dasar interaksi dalam masyarakat Jepang.

Kesadaran akan rasa terima kasih dan tahu balas budi menjadikan seseorang selalu terikat dengan si pemberi budi. Meskipun berdasarkan penggambaran yang terdapat dalam lakon ini si pemberi budi tidak secara gamblang menuntut pengembalian budi baik, namun si penerima 
dituntut untuk sadar atas kenyataan adanya ikatan budi tersebut yang akan mengikat mereka seumur hidup. Respon terhadap ikatan ini menjadi dasar kepatutan dan merupakan standar nilai "baik" dan "buruk" yang terdapat pada seseorang. Ketidakmampuan seseorang dalam menjalankan kewajiban inilah yang memunculkan rasa bersalah dan malu, yang menyebabkan mereka untuk melepaskan kewajiban ini dengan cara bunuh diri. Pilihan tindakan bunuh diri ini merupakan jalan yang dianggap tepat untuk mengakhiri hidup dengan cara yang terhormat, daripada harus hidup menanggung malu.

Nilai-nilai kehidupan yang terkandung dalam lakon ini adalah pemenuhan tanggung jawab, kesungguhan hati dalam menjalankan kewajiban, dan kehormatan diri. Nilai-nilai tersebut turut ditopang oleh budaya malu yang terdapat dalam budaya masyarakat Jepang yang menjadi ramburambu bagi masyarakat Jepang dalam bertindak dan berperilaku.

\section{DAFTAR PUSTAKA}

[1]. Befu, Harumi. Japan An Anthropological Introduction. New York: Chandler Publishing, 1971.

[2]. Budiman, Kazuko. Sastra Agama Endo Shusaku: Dilema Memahami Tuhan, Depok: ILUNI KWJ, 2006.

[3]. Ernst, Earle. The Kabuki Theatre. Honolulu: The University Press of Hawaii, 1974.

[4]. Jones Jr, Stanleigh H. Sugawara and the Secrets of Calligraphy, Translation from the Oriental Classics. New York: Columbia University Press, 1985.

[5]. Martin, Bronwen and Felizitas Ringham, Dictionary of Semiotics, London: Cassel, 2000.

[6]. Meisaku Kabuki Zenshu 2: Maruhon Jidaimonoshu 1. Tokyo: Tokko-Shogensha, 1968.

[7]. Sakaguchi, Hiroyuki, et al, Joruri no Sekai, Tokyo: Sekai Shisosha, 1992.

[8]. Shoko, Kodama, Eigode Hanasu Nihon no Dento Geino, Tokyo: Kodansha, 2000. 